\title{
XXII. Extract of a memoir on the temperature of the water of the sea, both at the surface and at different depths, along the shores and at a distance from the coast
}

\section{M.F. Peron}

To cite this article: M.F. Peron (1805) XXII. Extract of a memoir on the temperature of the water of the sea, both at the surface and at different depths, along the shores and at a distance from the coast, Philosophical Magazine Series 1, 21:82, 129-133, DOI: $10.1080 / 14786440508676688$

To link to this article: http://dx.doi.org/10.1080/14786440508676688

\section{Published online: 18 May 2009.}

Submit your article to this journal $\sqsubset$

Џ Article views: 3

Q

View related articles 
XXII. Extract of a Memoir on the Temperature of the Water of the Sea, loth at the Surface and at different Depths, along the Shores and at a Distance from the Coast. By M. F. Peron, Naturalist on the French Expedition to New Holland*.

" $\mathrm{O}_{F}$ all the experiments in natural philosophy," says M. Peron, "there are few the results of which are more interesting and more curious than those which form the subject of this memoir. The meteorologist must derive from them valuable data in regard to atmospheric observations in the middle of the ocean: they may furnish to the natutalist knowledge indispensably necessary in regard to the habitation of the different tribes of marine anmals; and the geologue and philosopher will find in them the most certain facts in regard to the propagation of heat in the middle of the seas, and of the physical state of the interior parts of the globe, the deepest excavations of which can scarcely go beyond the surface. In a word, there is no science which may not derive benefit from the results of experiments of this kind. How much then ought we to be surprised that they have hitherto excited so little attention!"

Proceeding then to an account of the observations which may be made at the surface of the sea, and which he him: self pursued from lat. $49^{\circ}$ north to lat. $44^{\circ}$ south, repeating them four times a day,--at six in the morning, at noon, at six in the evening, and at midnight, - $-M$. Peron deduces from them the following results:- " The temperature of the surface of the sea, colder at noon than the atmosphere, and warmer at midnight, is nearly in equilibrium with that of the morning and evening, in such a manner, however, that the mean term of a given number of observations is more considerable for the water of the sea."

By a very happy application of these first results $M$. Peron easily proves; that the supposed heating of the waves is a mistake of sensation produced by the more considerable cooling in- a given time of the atmosphere than of the waves. The pronf he has adduced seems to be as simple as it is incontestablé. This prejudice; which is as old as Aristotle, and which the incomplete experiments of Forster and Irving did not admit of being entirely rejected, not: withstanding the supposition of a principle contrary to

* From the Gounalde Pbysique. Brumaire, an 13.

Vol: 21. No. 62. Murch 1805. I

those 
those advanced by sound philosophy, will in fulure be entirely proscribed; and M. Peron substitutes in its stead this conseduence of the experiments which he made on this subject.

The relative temperature of the water of the sea increases during its agitation, but its alsolute temperature always decreases.

The second section of M. Peron's memor contains an account of experiments which may be made at great depths. The author here establishas a great distinction between experiments of this kind made along thie coasts, and those repeated in the open seat at a great distance from the continents and large islands. From lis examination of experiments of the first kind, whose made along the coasts by. Saussure and Marsigli in the Mediterranean; by Donati in the Adriatic; and by himsclf in the sea which washes the western coast of New Holland, it results that, cateris paritus, the temperature of the sea along the coasts is greater at equal depths than in' the middle af the ocean; that it seems to increase as one approaches the shores; and that these writers themselves furnish objections against the uni, form temperature of $10^{\circ}$, which bas hitherto been admitted as the mean temperalure of the interior part of the globe either in its solid or liquid part.

For the above experiments, and those about to be mentioned, $M$. Peron emploved an apparatus, invented by himself, which appears indeed to be superior to all those hitherto employed for the same purpose. By arranging successively around his thermometer a stratum of air, glass, charcoal, wood, tallow, and resin, hè was able to unite under a very small volume all those bodies which ane the worst conductors of caloric, and in such an order, that this property of being a bad conductor necessarily became still léss; M. Peron Ibaving set out from this principle, that calorie, as well as electricity, can with the greater difficulty. penetrate a stratum of a given thickness, as, the bodies which compose it are more different in their nature. This part of the author's labour has been wiversally approved.

The anthor then proceds to the iemperature of the sea at great depths:- "We have now arrived," says he, "at the third and ninth part of the experiments which might be artempted on the heat of the sea, water. It is also the most delicate and the most interesting, in consequence of the vaInable data it may furmist us in regard to the internal physical state of the globe at depths which cannot be reached in the olid part." He then gives the result of the experi- 
ments which he made successively in the neighbourhood of the equator at the depth of $300,500,1200$, and 2144 feet.

This consequenee, which no doubt is new and very interesting, results, namely, that the tempcrature of the water of the sea decreases in proportion to the depth. The difference obtained by $M$. Peron in his last observation at the depth of 2144 feet, was $19^{\circ}$ of Reaumur between the temperature of the surface and that at this depth.

Having given the result of his particular observations, the author examines the experiments of the same kind which were made before. "If we except," says he, " the celebrated traveller whose return has excited universal joy among all the friends of science, and who attended also to this object, but whose results and apparatus I am still unacquainted with*, three persons only have made accurate observations in the open sea on the temperature of the waters, viz. Irving, Forster, and myself. By a very uncommon accident, our experiments were repeated at three of the most opposite points of the globe. By Irring, during the voyage of the honourable Mr. Phipps, afterwards lord Mulgrave; to the North Pole; in the expedition of captain Cook to the South Pole, they were continued by Forster to the 64th degree south, beyond which no navigator had been able to advance; and I myself, placed, as I may say, between these extremes, made all my experiments in the neighbourhood of the equator. It would certainly be difficult to find any other fact in physics where so many points of compatrison can be enimerated; and yet we shall find the results of these different experiments reproduced,every where analogous to those which I shall here exhibit."

In Forster's experiments, indeed; we find that the temperature of the sea decreases successively from the 16 th of Reaumur to the term zero of the same thermometer, and it continually decreases the greater the depth. The ingenious experiments of Dr. Irving reproduce the same results with still more interest, since at the depth of 3,900 feet he obtained two degrees below zero of Reaumur's scale:

M. Peron then takes a rapid view of the very incomplete experiments of Ellis, Wallis, Bradley, and Baldh, and the anonymous ones collected by Kirwan : he is satisfied with observing, that they all concur to confirm the principal results of his own experiments, and those of Forster and Irving. He concludes with a greneral view of the same re-

* Mr. Humboldr ras still at Bourieatr. 
sults, and of the geological consequences which may be deduced from them.

The temperature of the sea water decreases according to the depth. All the resilts of the observations hitherto made on this point, concur in proving that the deepest gulphs of the sea, as well as the summits of the highest mountains, are continually covered with ice, even, mider the equator: whence it must necessarily follow that a very small number of animals and.vegetables can live there, if any exist at all. "Analogous results have proved," continues the author, " that a similar cooling existed at great depths in the principal lakes of Swisserland and Italy. The observations of Georgi, Gmelin, Pallas, Lcdyard, and Patrin, in Siberia, and those of that accurate observer Saussure, prove that the case in regard to the bosom of the earth has always been the same when experiments have been made at the bottom of mines. Similar results were obtained in America by Shaw, Mackenzie, Umfreville, and Robson. Ought not so many facts united to leave us in some uncertainty in regard to this theory, so generally admitted, of an interior central fire which maintans a uniform and constant temperature of $10^{\circ}$ in the whole mass of our globe, whether solid or liquid? Shall we not one dav be obliged to recur to this old principle, so naturat, and so agrceable besides to all the phxnomena which daily take place before our eyes? The only source of the hear of our globe is that great luminary by which it is enlightened: without it, without the salutary influence of its rays, the rhole of our earth, soon congealed in every point, would be only an inert mass of ice. 'The history of the winter of these polar regions would then be that of the whole planet."

However singular this last consequence of $\mathrm{M}$. Peron miy appear, however contrary it may be to our present.idcas in regard to the internal state of nur globe, it must be allowed that the facts collected by this naturalist in support of his opinion are so numerous, and there prevails so much agreement in all the results obtained by obscrvers, so different in so many different places, and at periods so distant, and with apparatis so little suscrptible of comparison, that no objection can be made to it by the respectable body before whon it is laid.

In the last place, the experiments of M. Humboldt, entirely analogous to those of Mi. de Peron, to whom the Prussian traveller was eager to pay a public tribute of praise, give it a new degree of weight. 
* This consequence of M. Peron," say the commissioners of the Institute, "appears to us the more probable, as it now proves the origin of those mountains of ice which in the polar regions have hitherto impeded the progress of the European navigators: it makes us readily comprehend how masses of ice, detached from the depths of the sea to float at the surface, can constitute in these regions projecting mountains of ice which simple congelation could never effect under that form."

This ingenious theory, therefore, of an interior central fire maintaining a uniform temperature of about 10 degrees throughout the whole mass, whether solid or liquid, of our globe, experiences at present the fate reserved, som or late, for almost all human theorics. The calculations of Leibnitz, who first conceived it ; the eloquence of Buffon, who decided his triumph, ought however, it would seem, to have secured to it a longer and more peaceable existence.

We shall terminate this extract with the opinion given on this subject by the commissioners of the Institute charged to give in a report upon it. "The memoir of M. Peron," say they, "seems to us to deserve great attention from philosophers: it is written with method, precision, and clearness. The experiments, of which the author gives an account, seer to have been made with that care and attention which are capable of ensuring the exactness of the results which they have furnished. We are therefore of opinion that this memoir deserves the approbation and even the praises of the class, and that it ought to be printed among those des Savans Etrangers. We will venture to add, that this is not the only claim of $M$. Peron to the gratitude of all those who are fond of the sciences; his labours during his voyage will considerably tend to enlarge the boundaries of the natural scicnces."

XXIII. An Analysis of the magnetical Pyrites; with Remarks on some of the other Sulphurets of Iron. By Charles Hatchett, Esq. F.R.S.*

\section{$\S I$.}

$O_{F}$ the varions metallic sulphurets which constitute one of the grand divisions of ores. none appear to be so universally dispersed throughout the globe as the sulphuret of

* From the Transations of the Royal Society of London for 1804 . 